\title{
ДУХОВНА ЕВОЛЮЦІЯ ЛЮДИНИ ЯК НАПРЯМ ЗБЕРЕЖЕННЯ І РОЗВИТКУ ЛЮДСТВА
}

\author{
Ю. Д. Бойчук \\ д. пед. н., професор, проректор з наукової роботи \\ Харківського національного педагогічного університету імені Г. С. Сковороди

\section{М. С. Гончаренко} \\ д. б. н., професор, професор кафедри «Валеології» філософського факультету \\ Харківського національного університету імені В. Н. Каразіна
}

У відповідності до духовних і філософських учень шлях розвитку людини включає підйом і сходження від людини духовної до людини божественної. Це шлях пізнання себе.

Цей шлях духовного зростання містить в собі три етапи: очищення, осяяння і вдосконалення.

Перший етап духовної еволюції людини - це очищення його душевної природи. Очищення має багато типів і ступенів: фізичне, моральне, ментальна чистота. Моральна і ментальна чистота $є$ складовими душевної чистоти.

Процес очищення - це усвідомлене прагнення подолати свій егоїзм, свої моральні недоліки, виробляти в собі прагнення жити і працювати заради інших.

Це безперервна праця над власним вдосконаленням, над умінням контролювати свої емоції, почуття, думки, усвідомлено культивувати в собі вищі почуття і прагнення. Згідно з вищими законами, жодна людина не може долучитися до вищих знань, якщо вона не пройшла перед цим випробувань, які підтвердили б іiі моральну готовність до подальшого навчання і оволодіння новими таїнствами.

Другий етап духовної еволюціï - це осяяння людини. Осяяння відбувається з людиною тільки в тому разі, якщо людина має вище духовне «Я», розвинене до такого рівня, коли вона стає здатною вступати в енергоінформаційну взаємодія з духовними джерелами, що приводять до розкриття інтуїції, тобто внутрішнього духовного бачення. Вище духовне «Я», згідно з теософією, має у своєму складі вищу волю (Атма), вищу любов (Будха), вищий розум (Манас). Кожна людина проходить свій власний шлях одухотворення.

Таким чином, духовний світ самоеволюції кожної людини є інтуїтивно-особистісним, який відбувається в напрямку від пізнання себе до пізнання Бога в собі.

Фактично, другий етап — це робота над своїм духовно фізичним самовдосконаленням.

Tpemiŭ eman - етап самореалізації та самокорекції, спрямованої на формування позитивних якостей (конструювання думок, вищих почуттів виховання доброї волі). Необхідно змінити не тільки зовнішній образ життя людини, а й весь внутрішній напрям думок, почуттів для морального оздоровлення своєї психіки.

Четвертий eman - це робота зі своїм вищим духовним «Я» в напрямку виходу за межі свого власного «Я» і з'єднання з Творцем.

Це самостійний і чисто індивідуальний шлях творчого співробітництва і взаємодії з релігійною, філософською та ін. відповідною літературою, духовним учителем.

Таким чином, прагнучи змінити на краще світ, кожна людина має починати з себе, тому що, вдосконалюючись, змінюючи особистість, ми змінюємо таким чином і навколишній світ, і саму планету.

Цю ідею взаємозумовленості і взаємозалежності, вдосконалення суспільства від духовного самовдосконалення кожної окремої особистості знаходимо у багатьох мислителів, філософів. Про цей феномен писали Платон, Г. С. Сковорода, Шрі Ауробіндо, М. і О. Реріхи, В. Аксьонов і багато інших, саме вони відзначали, що змінити колективну свідомість можна лише за умови вдосконалення індивідуальної свідомості кожної окремої людини.

Аналіз літератури з проблем шляхів розвитку духовності, представлений у роботі Т. Тюріної, дозволяє дати наступні рекомендації:

- виховання з раннього дитинства у сім'ї та школі внутрішньої потреби у самопізнанні та самовдосконаленні, творчій роботі, гармонізації навколишнього середовища - жити і працювати заради інших;

- систематична безперервна робота над самопізнанням і самовдосконаленням своєї фізичної, психічної і духовної природи;

- усвідомлене очищення своєї психіки від негативних психологічних проявів: егоїзму, самості;

- формування високих почуттів: конструктивного мислення, доброї волі, творчої інтуїції;

- усвідомлене культивування таких кращих душевних якостей, як любов, милосердя, співчуття нужденним, почуття емпатії.

Усе вищевикладене $є$ серйозним теоретичним і практичним обгрунтуванням необхідності включення питань виховання духовності в освітній процес на всіх стадіях його функціонування. Цим питанням присвя- 
чені праці Шевченко Г. П., Поміткіна Е. А., Савчина М. В., Бойчука Ю. Д., Гончаренко М. С., Тюріної Т. Г. та інших українських учених.

Кожна людина має усвідомлювати високу відповідальність за свої думки, слова, вчинки.

Таким чином, виховання розуму, як однієї зі складових душевного розвитку людини, включає:

1) усвідомлений самоконтроль, самоаналіз і самокорекцію власного мислення з метою очищення його від негативних, руйнівних, нігілістичних, деструктивних думок;

2) культивування позитивного, конструктивного мислення;

3) формування волі - свідомої саморегуляції людиною своєї поведінки і діяльності, що регулюється функцією мозку;

4) воля виконує дві взаємопов’язані функції - активації і гальмування, залежно від мети. На вищих рівнях прояву воля передбачає духовні цілі, переконання та ідеали. На шляху духовного самовдосконалення людина має навчитися долати перешкоди не тільки зовнішні, але, перш за все, внутрішні, контролювати власні схильності, почуття, думки, вчинки.

Серед сучасних педагогічних технологій, що сприяють гармонійному розвитку духовної, психічної та фізичної складових здоров'я, провідне місце посідає метод підвищення культури мислення. Аналіз різних технологій $з$ формування культури мислення в ході навчально-виховного процесу $є$ завершальною частиною цього розділу. Особлива увага приділяється позитивному мисленню як провідній технології духовного оздоровлення.

У процесі дослідження здоров'я індивіда необхідно керуватися новими уявленнями про структурну організацію людини з позицій холістичного підходу, тобто розвивати розуміння механізмів функціонування і взаємодії свідомості, душі та тіла як цілісної системи, вивчати і оцінювати стан духовної, психічної та фізичної складових здоров'я.

На стан духовного здоров'я в значній мірі впливають позитивні та негативні фактори.

До факторів позитивного впливу можна віднести:

- наявність чітко визначеної мети життя, до якої прагне людина;

- формування менталітету, спрямованого на здоров'я;

- рівень культури - загальної, моральної, духовної;

- соціально корисна діяльність, високий рівень професіоналізму;

- задоволеність життям (відчуття щастя і благополуччя).

Серед негативних факторів впливу на духовне здоров'я слід відзначити:

- відсутність або неясність розуміння сенсу життя;

- надання пріоритетного значення в житті матеріальним благам, речам, кар'єрі;

- відсутність культури здоров'я;

- соціальна ізоляція, тобто відсутність соціальної підтримки;

- недоліки в організації служби валеологічної діагностики дітей, молоді та дорослих, зокрема недостатня оснащеність ї̈ сучасним інструментарієм, методами оцінки стану духовного здоров'я.

Оцінка якості духовного здоров'я передбачає використання засобів і методів його діагностики, а також вивчення оптимальних норм реакції на вплив навколишнього середовища, які постійно змінюються.

Розглядаючи проблему діагностики показників духовного розвитку особистості, слід підкреслити, що більш за все вони корелюють з рівнем духовного потенціалу, що $є$ відображенням ступеня самоорганізації людини, рівня ії̈ свідомості, спрямованості на загальнолюдські духовні ідеали і цінності.

Значний внесок у розвиток духовного потенціалу учнів вніс доктор психологічних наук, професор Е. О.Помиткін. Саме ним вперше в Україні було розроблено навчально-методичний посібник з діагностики досліджень духовного розвитку школярів в процесі навчання [10].

Подальші наукові пошуки Е. О. Помиткіна були присвячені вивченню психології духовного розвитку особистості [9].

В даний час видатний український педагог ставить питання про потребу зміни змістовних орієнтирів освітнього процесу з акцентом на збереження здоров’я і психофізичних реакцій організму. Узагальнення існуючих наукових позицій свідчить, що в даний час $є$ два основні підходи до визначення духовності - змістовний і функціональний.

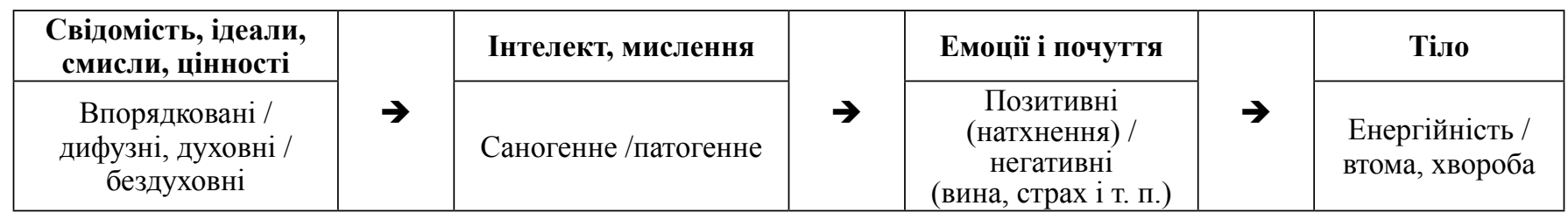

Рис. 1 
Таким чином, резонанс є не тільки формотворчим явищем, але і дійсним засобом корекції цієї форми засобом відновлення природної вібрації організму і його гармонії.

Ця особливість функціональної психічної дихотомії суспільства повторює структуру глобальної інформаційної сфери, де два світи (лівий і правий) вкладені один в один, і наявність цих чітко визначених протилежностей призводить до коливальних (а на певних етапах і драматичних) процесів в реальному житті.

Протилежностям властиво перетікати одна в одну, тобто, по черзі домінувати.

Духовність - це робота інтуїції і логіки - «антиматеріальних» психічних функцій. Тому можна з упевненістю сказати, що початок третього тисячоліття знаменує настання періоду розквіту духовності і знань. У найближчі роки попит на людей науки і мистецтва буде підвищуватися.

Відповідно до змістовного підходу духовність пов'язують з такими сенсоутворюючими категоріями, як Краса, Доброта, Істина (за Платоном) або Віра, Надія, Любов, Покаяння (в Християнському релігійному контексті). Спрямованість на Красу передбачає естетичне світосприйняття особистості, самовдосконалення і вдосконалення світу; спрямованість на Доброту — гуманістичне світосприйняття, самовдосконалення і вдосконалення світу; спрямованість на Істину — пізнання, самопізнання і просвітництво. Протилежністю духовності $є$ бездуховність, яка характеризується Нерозсудливістю, Злом (нанесенням шкоди собі та іншим), Неправдою (несправедливістю, викривленням дійсності).

Відносно функціонального підходу - духовність характеризується ієрархічною домінантою розвитку вищих психічних функцій людини. До цих функцій, на думку Л. С. Виготського, І. Д. Беха відносять свідомість, самосвідомість, вольову саморегуляцію, досконалість особистості.

Низький рівень розвитку духовності пов'язаний $з$ при-

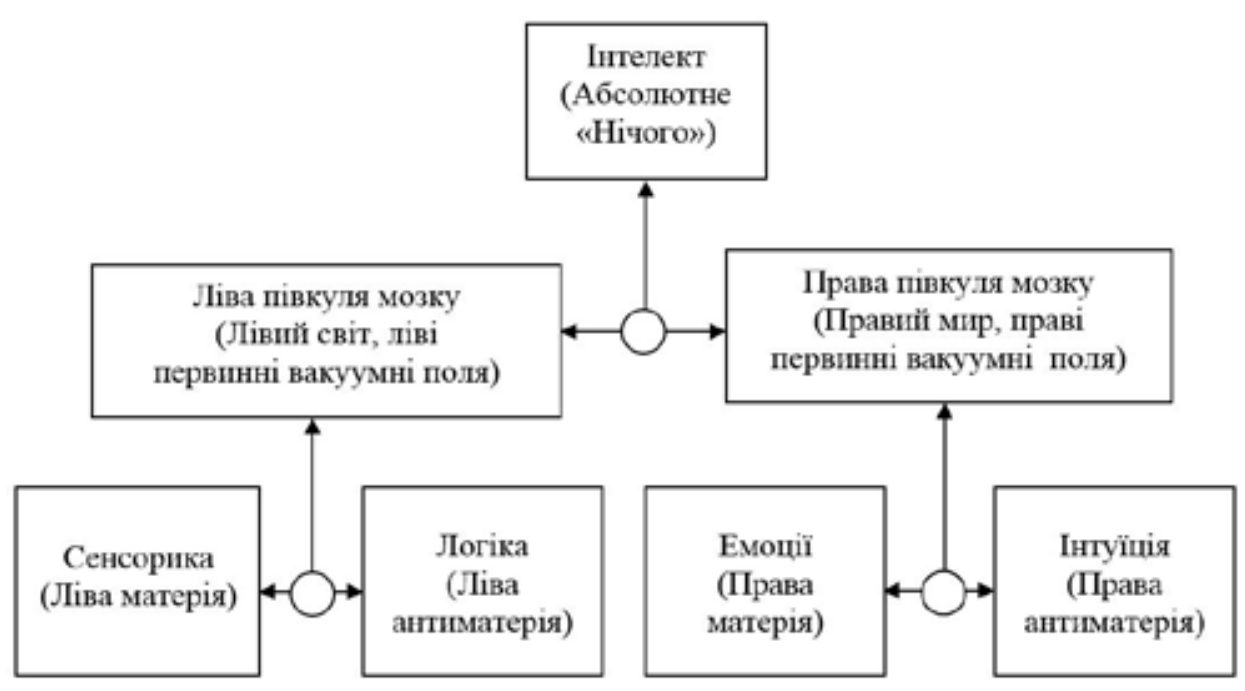

Рис. 2 Дихотомічна сила інтелекту мітивізмом, обумовленістю поведінки первинними інстинктами самозбереження і продовження роду. Наведені підходи повинні бути об'єднані в визначенні і розумінні духовності як найбільш важливої людської характеристики.

3 огляду на змістовний і функціональний підходи, духовність визначається як специфічна людська якість, яка характеризується усвідомленням єдності Буття і обумовлює прагнення особистості до вдосконалення внутрішнього і зовнішнього світу, спрямовує іiі до реалізації у власному житті ідеалів Краси, Добра, Істини.

В результаті теоретичного аналізу та узагальнення даних з даної проблеми встановлено, що духовний потенціал характеризує вищий ступінь людської самоорганізації, яка визначається високим рівнем свідомості, самосвідомості і вольової саморегуляції особистості, обумовлює свідому стійкість, рішучість, непохитність, відданість власним покликанням, життєвій місії, відрізняється спрямованістю особистості на вищі духовні ідеали, смисли, цінності (особливо естетичні, гуманістичні, екологічні, валеологічні, пізнавальні), самовдосконалення і самоорганізацію.

Підводячи підсумок, слід зазначити, що розвиток духовного потенціалу дітей і молоді є завданням державного значення, а ставлення держави до його виконання $є$ показником суспільного прогресу.

Значний вклад у розвиток духовного потенціалу учнів у навчальному процесі внесли дослідження проф. д.П.н. Бойчука Ю. Д. [2]. Ним розглянуто зв'язок між станом духовності школярів і структурними компонентами формування духовного здоров'я у навчально-виховному процесі [Рис. 4, Рис. 5].

Забезпечення духовного здоров'я особистості та формування ії здатності до самоактуалізації мають багато точок перетину в освітній діяльності. Передусім мова йде про формування в особистості цілого комплексу якостей та здібностей, які, будучи спрямовані на їі саморозвиток, одночасно $є$ і механізмами забезпечення духовного здоров'я. Серед таких якостей насамперед слід указати на розвиток потреби та здатності особистості до усвідомленого самопізнання, спрямованість до самоідентифікації, діяльність у напрямі саморозвитку та розкриття власних здібностей, формування мотивації до особистісної саморегуляції, на забезпечення освітніми впливами здатності особистості до саморозвитку та самоактуалізації впродовж усього свого життя $[2,10]$. 


\section{Структурна і функціональна організація духовного потенціалу}

За рекомендаціями професора Е. О. Помиткіна при вивченні духовного потенціалу слід відстежувати принципи його духовно-особистісної інтеграції, які використовуються для діагностики розвитку духовного потенціалу людини і які є проявом його особистісного зростання:

• Принцип ієрархічності.

• Принцип ціннісно-смислової орієнтації.

• Принцип вищої доцільності.

• Принцип цілісності.

• Принцип свідомої взаємодії.

- Принцип розвитку свідомості.

- Принцип свободи волевиявлення.

- Принцип детермінованості зовнішнього і внутрішнього.

У функціональному вимірі діагностика духовного потенціалу повинна бути спрямована на: 1) дослідження його кількісних характеристик (рівень розвитку); 2) виявлення рівня свідомості і ціннісних орієнтацій особистості; 3 ) виявлення рівня відповідальності як ознаки волі і духовної самосвідомості; 4) дослідження духовної ідентифікації, децентрації, рефлексії, трансцендентності, усвідомлення, буття (буттєвої) єдності; 5) визначення рівня актуалізованності мотивів духовного розвитку.

У змістовному вимірі необхідно

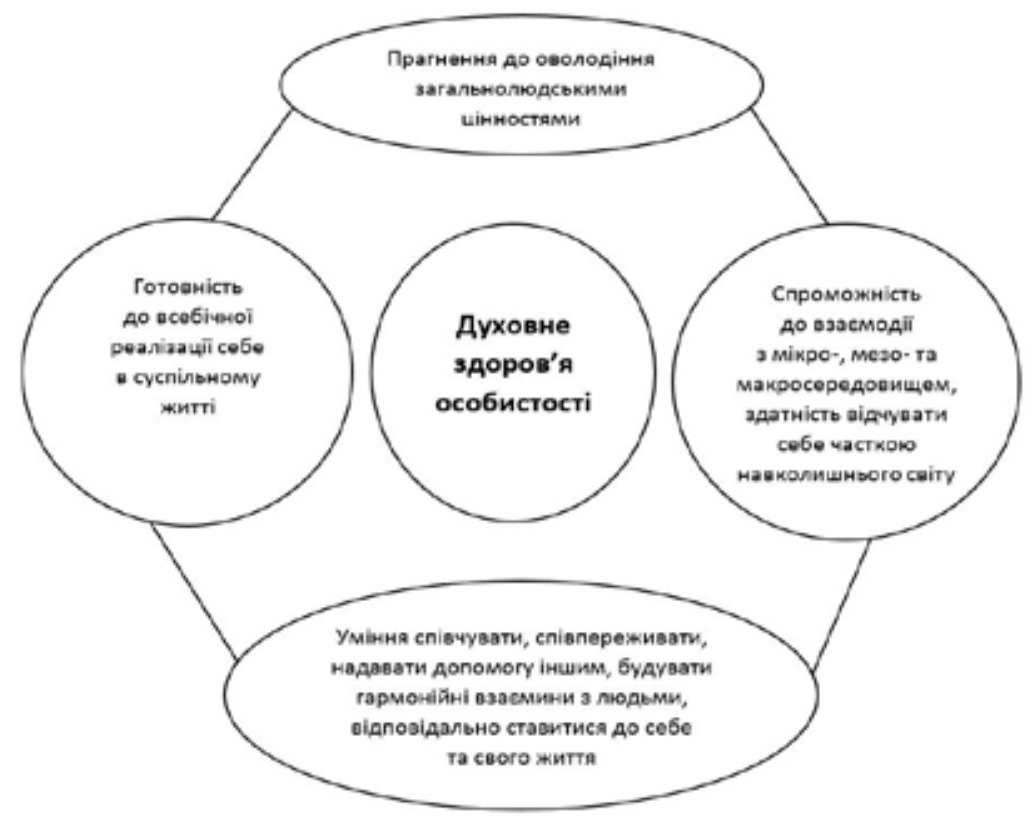

Рис. 4. Духовне здоров’я особистості з'ясувати якісні ознаки розвитку духовного потенціалу особистості:

1. Наявність і усвідомлення духовних ідеалів.

2. Наявність і значимість духовних смислів.

3. Ціннісну орієнтацію, важливість духовних цінностей (естетичних, гуманістичних, екологічних, валеологічних, пізнання і самопізнання, духовного самовдосконалення та самореалізаціі) в загальній системі цінностей особистості.

4. Спрямованість мислення на вищі духовні категорії, осмислення життєвих сенсів, свого призначення і життєвого шляху.

5. Переважна більшість вищих позитивних емоційно-чуттєвих станів особистості.

Отримана діагностика як у функціональному, так і в змістовному вимірі свідчить про наявність і актуалізованність духовного потенціалу особистості. Крім цього, діагностика повинна бути спрямована на виявлення:

1. Особливостей прояви духовного потенціалу особистості в спілкуванні.

2. Духовної спрямованості поведінки особистості в умовах колективу.

3. Особливостей прояву духовного потенціалу особистості в діяльності і в життетворчості.

Всі діагностичні підходи повинні здійснюватися в рамках етичних норм. Духовні потреби дитини є індикатором, який свідчить про іiї духовний потенціал, з іншого боку це камертон, який задає тональність особистісного розвитку в руслі Краси, Добра, Icтини, Любові.

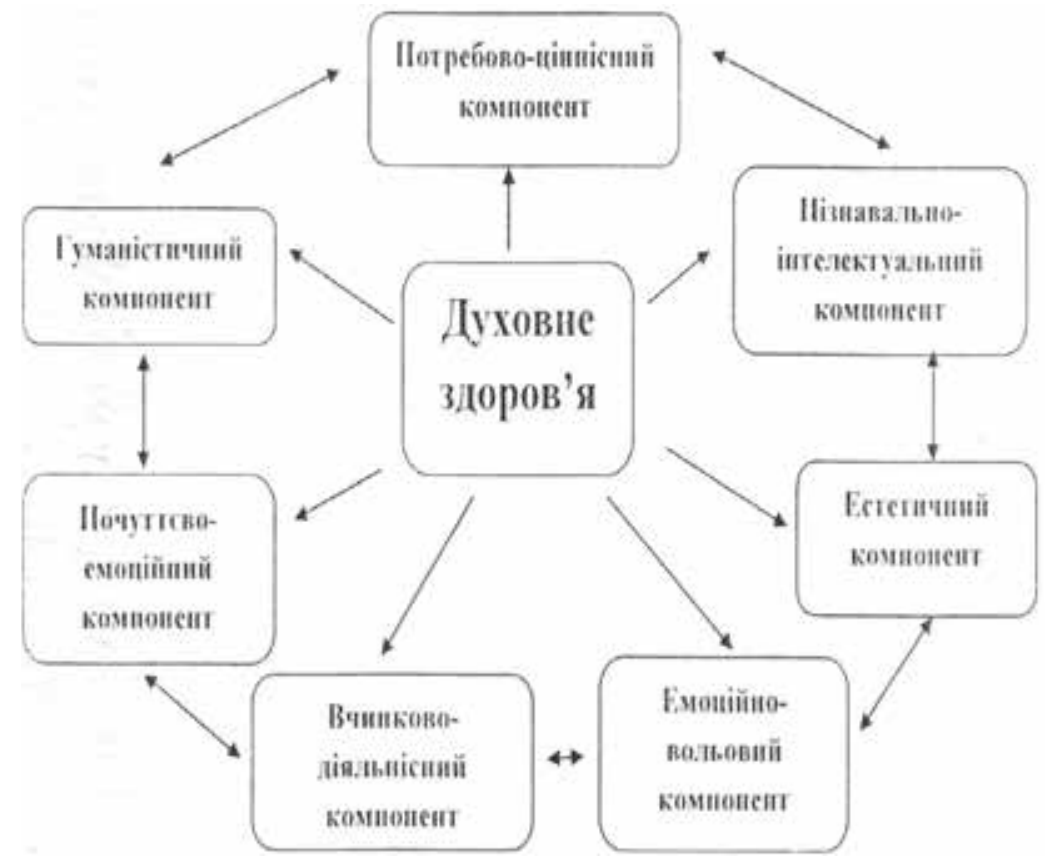

Рис. 5 Структурні компоненти духовного здоров’я 


\section{Духовність особистості \\ Емоції і почуття особистості високої духовності}

Відповідно до сучасних уявлень про структурну організацію людини, іiі духовний потенціал визначається гармонічною взаємодією духу, душі і тіла, а точніше станом (активністю) їі тонких тіл: астрального, ментального, каузального, будхіального і атманічного. [9] Фактично це світ взаємодії емоцій, почуттів і думок. Цими питаннями цікавилися як стародавні мислителі (Геракліт, Марк Аврелій, Платон, Піфагор та інші), так і сучасні філософи, педагоги (Джеймс, В. П. Зінченко, І. А. Зязюн, В. А. Татенко та інші).Вперше ми стикаємося 3 керуванням емоціями і почуттями у Патанджалі, який вважав, що людина повинна культивувати три основних емоційних стани: радість, співчуття і доброзичливість. Їх підтримка в собі $є$ найбільш сприятливим для розвитку духовного потенціалу людини і виконання нею своєї духовної місії. [10]

Таку ж точку зору розвивав Марк Аврелій: «В одному шукай радість і заспокоєння, щоб від одної загальнокорисної справи переходити до іншої».

Ісус Христос своїм послідовникам радив постійно підтримувати свій позитивний стан. У стародавній філософській літературі є багато порад щодо управління своїми емоціями. Емоції служили одним з головних механізмів внутрішньої регуляції. Почуття $є$ вищим продуктом розвитку емоцій.

Емоції людини можуть бути як усвідомленими, так і неусвідомленими. Конфлікт між ними $€$ причиною неврозів.

За впливом на сприйняття емоції діляться на позитивні і негативні. За впливом на організм їх класифікують на: стенічні, які підвищують активність, енергію, дихання, сприяють оздоровленню, а також астенічні, які пригнічують людину.

За якістю (модальністю) емоції розрізняються по інтенсивності, тривалості, глибині, складності, функціям, спрямованості, будові. Як правило, спочатку у людини з'являється короткочасна емоція, далі вона може посилитися і перетворитися в настрій, а з часом - в глибинні почуття.

Згідно хвильової організації енергоінформаційної структури людини емоції можуть виникати на різних рівнях психічної складової, тобто на астральному, ментальному і навіть на каузальному (причинному) рівнях. Залежно від тривалості дії емоції можуть сприяти порушенню функціонального стану організму і приводити до виникнення захворювань або зриву адаптаційно-пристосувальних можливостей організму.

Розглядаючи особливості емоційно-чуттєвої сфери людини з високим духовним потенціалом, проф. Е. А. Помиткін скористався духовно-особистісним підходом, грунтуючись на функціональному і змістовному вимірі.

Так, оскільки в змістовному вимірі основними смислоутворюючими категоріями духовного розвитку $\epsilon$ краса, доброта, істина і любов, виділимо з емоційно-чуттєвих станів людини ті, які свідчать про актуалізацію духовного потенціалу особистості або неактуалізації. В якості позитивних естетичних емоцій і почуттів можна віднести ті, які пов’язані зі сприйняттям краси, співзвучності, гармонійності, досконалості.

Табл. 1

Емоційно-чуттєві стани особистості

\begin{tabular}{|c|c|c|c|}
\hline \multicolumn{2}{|c|}{ Позитивні } & Негативні \\
\hline Благоговіння & Можливість & Смак & Дисгармонія \\
\hline Велич & Гармонія & Співзвуччя & Дисонанс \\
\hline Досконалість & Натхнення & Такт & Низкість \\
\hline Захоплення & Обожнювання & & Потворність \\
\hline Краса & Окрилення & & Страждання \\
\hline Насолода & Святковість & & Цинізм \\
\hline Сприйняття & Урочистість & & Упередження \\
\hline
\end{tabular}

До гуманістичних моральних емоцій і почуттів відносяться такі, які пов’язані з совістю, піднесеністю або приниженням особистості. 
Морально-гуманістичні емоційно-чуттєві стани особистості

\begin{tabular}{|c|c|c|c|}
\hline \multicolumn{2}{|c|}{ Позитивні } & \multicolumn{2}{|c|}{ Негативні } \\
\hline Подяка & Обожнювання & Безжалісність & Нехтування \\
\hline Великодушність & Патріотизм & Байдужість & Презирство \\
\hline Відданість & Підтримка & Жорстокість & Приниження \\
\hline Гідність & Привітність & Заздрість & Вина \\
\hline Доброзичливість & Слава & Поверховість & Сором \\
\hline Доброта & Смирення & Неповага & Упередження \\
\hline Сдність & Співчуття & Лукавство & Холодність \\
\hline Жалість & Справедливість & Неприязнь & \\
\hline Милосердя & Умиротворення & & \\
\hline Невинність & Честь & & \\
\hline Зобов’язання & & & \\
\hline
\end{tabular}

Табл. 3

Інтелектуальні емоційно-чуттєві стани особистості

\begin{tabular}{|c|c|c|c|}
\hline \multicolumn{2}{|c|}{ Позитивні } & \multicolumn{2}{c|}{ Негативні } \\
\hline Впевненість & Осяяння & Анатомія & Сарказм \\
\hline Гумор & Передчуття & Байдужість & Смуток \\
\hline Зацікавленість & Подив & Відчай & Хвилювання \\
\hline Подив & Прозріння & Збентеження & Сумнів \\
\hline Зосередженість & Просвітлення & Невпевненість & Підозрілість \\
\hline Ентузіазм & Сконцентрованість & Неповага & Розчарування \\
\hline Інсайт & Інтерес & Туга & Рого \\
\hline
\end{tabular}

Резонанс, створений позитивними емоційно-чуттєвими станами, може привести до виникнення трансперсональних переживань, які проявляються станом розчинення, всеєдності, почуття любові, покори.

До вищих духовних переживань відносяться почуття пробудження, просвітлення. Таким чином, в змістовному вимірі особистість з високим духовним потенціалом переживає як звичайні людські почуття і емоції, так і специфічні трансперсональні стани. Що стосується функціонального виміру, особистість 3 високим рівнем духовності відрізняється не тільки широким спектром позитивних емоцій, а й емоційною стійкістю, яка досягається постійною вольовою практикою [9].

\section{Інтелект і мотивація особистості з високим рівнем духовності}

Згідно з існуючими зараз уявленнями, стан внутрішнього світу людини в значній мірі визначається особливостями інтелектуальної активності особистості, мотивами і потребами, які цю активність викликають. У сучасних психологічних концепціях інтелект розглядається як стійка структура розумових здібностей індивіда, система розумових операцій, серед яких - сприйняття, увага, мислення, пам'ять, уявлення.Високий потенціал духовності особистості накладає відбиток на всі наведені інтелектуальні процеси. Безумовно, превалює у них інтерес до духовних знань, накопичених людством.

Особистості з високим духовним потенціалом характеризуються прагненням до самовдосконалення, духовної самореалізації та загальної доброти, що дає їх мисленню особливої стратегічності і орієнтації на людство [9].

Емоційна врівноваженість таких людей визначається філософським світосприйняттям, здатністю особистості пам'ятати про Добро і ігнорувати Зло. Особливу відповідальність особистості з високим рівнем духовності несуть думки з переважаючим генеруванням позитивних образів (Краса, Добро, Істина, Любов).

Домінантність духовних потреб обумовлює спрямованість мислення на пошук духовно-значимої інформації, способів самопізнання і можливостей самовдосконалення, реалізації духовного потенціалу, побудови 
життєвого шляху на основі Краси, Доброти, Істини, Любові.

Аналіз змісту вищих духовних законів різних часів і народів показує їх приблизну однотипність. Як приклад хочеться привести настанову князя Київської Русі Володимира Мономаха, в якій він викладає уявлення про вдосконалення людини наступним чином:

«Стався до інших так, як хочеш, щуоб ставилися до тебе.

Укріплюй тіло і душу, просвітлюй розум.

Будь завтра кращчим, ніж ти є сьогодні. Чи не дозволяй сильним приниюувати слабких.

Не залишай хворих, не забувай про бідних.

Не май гордині ні в розумі, ні в сериі.

Пізнавши все хороше, пам'ятай, а чого не знаєи - тому вчись.

Живи для Батьківщини і люби людство».

Відповідно до принципів духовно-особистісного підходу, а конкретніше, принципів духовно-особистісної інтеграції, психологічні механізми розвитку духовності повинні забезпечувати духовне зростання особистості, оволодіння нею більш складними формами поведінки і діяльності. А. Адлер основним механізмом розвитку людини вважав боротьбу за вдосконалення, прагнення до реалізації життєвої мети щодо духовних ідеалів [9].

Ці питання висвітлені в роботах психологів В. Г. Алексєєва, О. І. Зотова, М. І. Бобнева, Є. П. Кознова, В. Г. Панок і багатьох інших [9]. 3 цього приводу академік І. Д. Бех зазначав, що «у виховній практиці використовуються механізми успадкування, ідентифікації, емоційного зараження, свідомості, самосвідомості і вольового зусилля [10].

У сучасній науці поняття ідентифікація розглядається в трьох площинах. По-перше, процес об'єднання себе

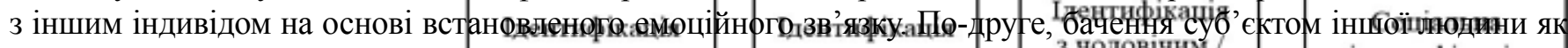

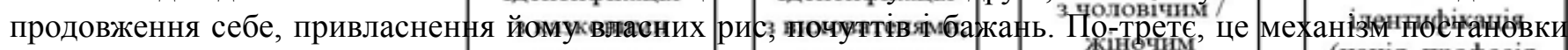

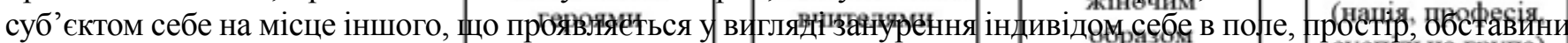
іншої людини, що призводить до засвоєння його ософистого сенсу.

Ідентифікація як психологічний механізм має важливе значення при формуванні у дитини стійкості до спокус і розвитку совісті [10]. Р соціальній пеихолотії ідентифікація розглядається нк найільш важливй

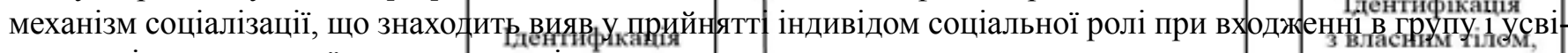
домленні ним групової приналежносъвітьками

Кінцевим результатом процесу ідентифікаціі $\epsilon$ придбання певної ідентичності. Вона можербунияк, ідеальною, так і негативною. Найчаетіше рөзғлядаєтрся розподіл ідентичності на біфлопічнувсөчріаяњну та духовну.

На рис. 7 представлені етапи біологічноі, соціальної і духовної ідентичності особистості.

Завдяки ідентифікації з іншими відбувається децентрація, яка може трансформуватися в самоідентифікацію особистості з вищою природою.

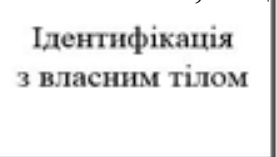
всім Буттям
Ідентифікапія 3 власним духовним «Я»
Рис. 7. Етапи біологічної, соціальної і духовної ідентифікації особистості 
Духовна самоідентифікація людини — це результат його еволюційно-історичного шляху від біологічного до соціального, від соціального - до духовного «Я». На вищих етапах духовної самоідентифікації відбувається усвідомлення «єдності з Першоджерелом, яке називається природою або Богом» — вважає T. I. Пашукова.

Серед інших механізмів особистісного зростання привертає увагу психологічний механізм децентрації, під яким розуміють подолання егоцентризму особистості. Цей процес супроводжується зміною точки зору, позиції суб'єкта в результаті зіставлення та інтеграції її з відмінною. Формування навичок децентрації лежить в основі здатності суб' єкта до прийняття іншої людини. Цей процес пов'язаний з рівнем розвитку когнітивної емпатії і визначає ефективність комунікативної взаємодії.

Таким чином, егоцентризм, який характеризується ізольованістю (споживання, самості) через децентрацію набуває любов, служіння, відданість.

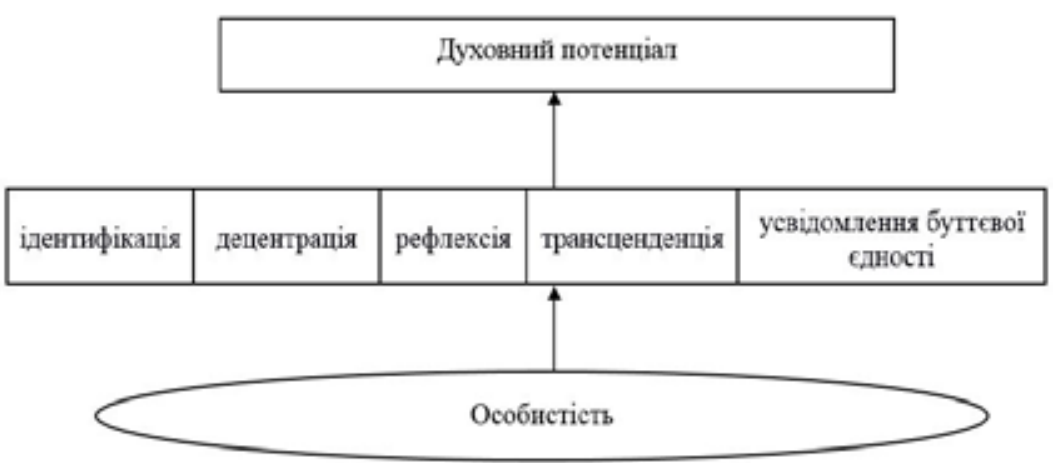

Рис. 8. Психологічні методи актуалізації духовного потенціалу особистості

І. Д. Бех зазначає: «У методичному плані педагог, який пращңює над подоланням духовної безпечності вихования, повинен перш за все розхитати сформовану у нього иіннісну структуру егоиентричного спрямування... Поступово педагог домагається переорієнтаџї мислення вихования... Таке саногенне мислення корисно тим, щз воно нейтралізує прояв почуттів, які не сприяють морально-духовному зростанню особистості і культивує вищі духовні переживання.

Під рефлексією розуміють здатність звертати увагу на свій внутрішній світ, міркувати над своїм психічним станом, піднятися над своїм буттям.

Психологічна рефлексія пов'язана 3 осмисленням людиною себе як цілісної особистості, яка сама реалізує і розвиває свою індивідуальність.

Духовна рефлексія забезпечує пошук і знаходження відповідей на головні питання: «Хто Я?», «Що роблю в цьому світі?», «Чи існують межі духовних можливостей?».

Осмисленість дозволяє особистості проаналізувати події власного життя, свого шляху і інтегрувати особистісні придбання в цінний духовний досвід.

Прагнення до ідеального, досконалого $\epsilon$ наслідком актуалізації, механізму трансценденції.

Поняття трансцендентної педагогіки все активніше входить в сучасну педагогіку.

Ю. П. Азаров, автор книг «Трансцендентна педагогіка» та «Основи трансцендентальної педагогіки» пише: «У філософіï, гуманітарних науках, в культурі найвищим є духовне, або універсальне, що позначається категоріями «транцендентне» $i$ «трансиендентальне»» [10]. Це ідеал виховання і освіти, який досягається за допомогою педагогічного мистецтва.

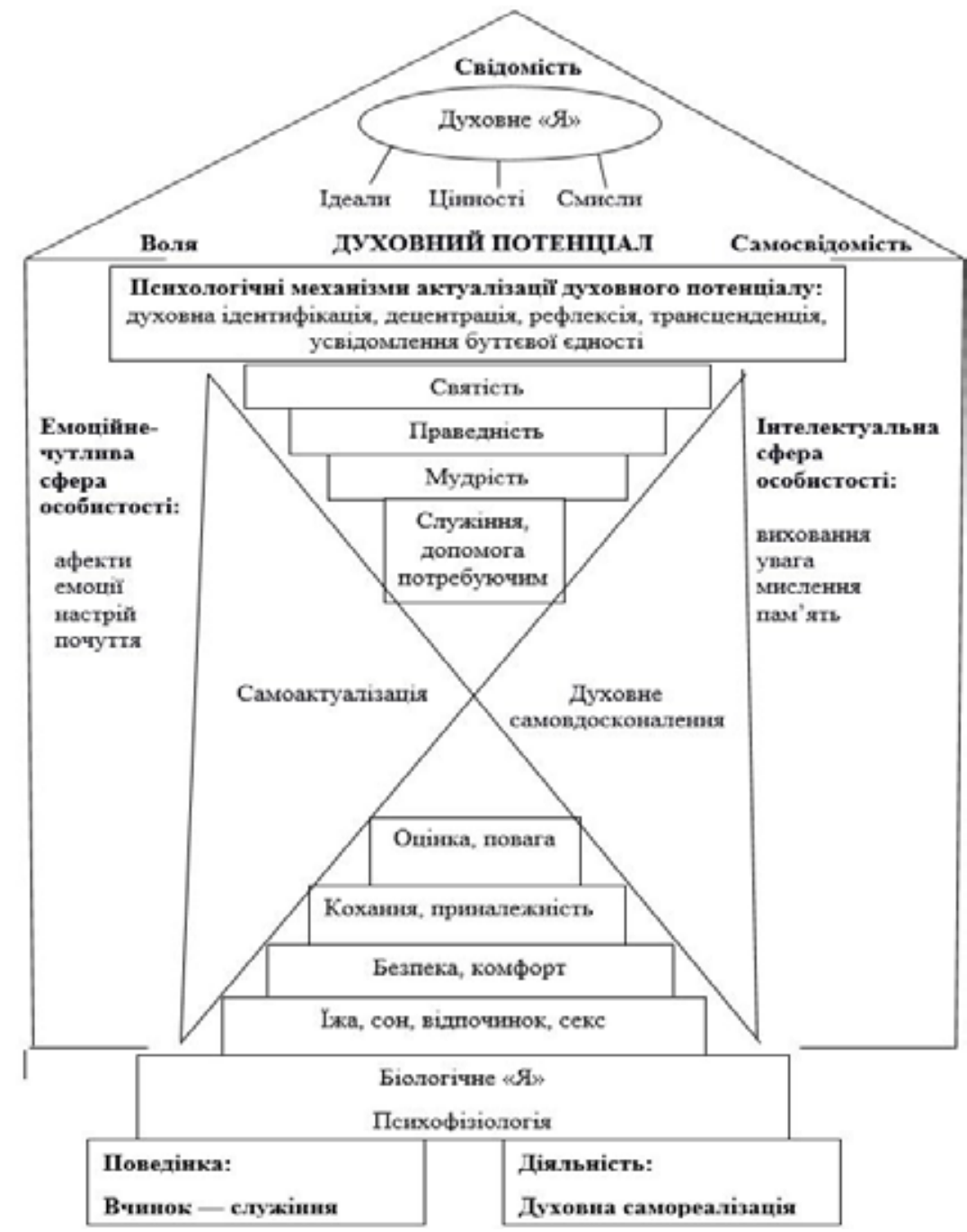

Рис. 9. Структурна організація духовного потенціалу особистості [9] 
У той же час трансцендентальна визначає ступені приближення до ідеалів навчально-пізнавальної діяльності, до ідеалів становлення творчої, духовно-правової особистості, як педагога, так і учня [3].

Метою трансцендентальної педагогіки є стимулювання духовно-творчих процесів, які в силу ірраціональності неможливо охопити логічними методами (свідомістю, мисленням, логікою). «Такі найбільш важливі явища, як осяяння, інтуїція, творчий порив, життєлюбність і людинолюбство, любов до своїх потенційних можливостей, до людей, любов до Батьківщини до рідного краю, часто буває не підвладна розуму, а усвідомлюються тільки в надрах ірраціональних глибин» [3].

Таким чином, механізм трансценденції здійснює перехід сфери реального через осяяння, інтуїцію, творчість, життєлюбність, людинолюбство в сферу ідеального.

На думку С. Л. Франка саме усвідомлення буттєвої єдності забезпечує зв'язок між різними поколіннями людства.

«Всеєдність людського життя, в силу якого будь-яке «Я» вкорінене в «Ми», живе і розвивається тільки в його лоні, має часовий вимір, в якому воно є надчасовим. Суспільство як духовна єдність, ніколи не поміщається в мить теперішній, в сьогоднішній день: воно існує тільки тоді, коли в ньому будь-який момент жсиве його минуле; його «сьогодні» $е$ тільки зв'язок між його «вчора» $i$ «завтра».

Таким чином, основними механізмами актуалізації духовного потенціалу особистості є: ідентифікація, децентрація, рефлексія, трансценденція і усвідомлення буттєвої єдності [9].

Сам же духовний потенціал характеризує вищий ступінь людської самоорганізації, яка визначається високим рівнем свідомості, самосвідомості, вольової саморегуляції особистості, формує свідому стійкість, непохитність, рішучість, відданість власним покликанням, життєвій місії, визначається спрямованістю особистості на вищі духовні ідеали, смисли і цінності, а саме: естетичні, гуманістичні, екологічні, валеологічні, пізнавальні, самовдосконалення та самореалізацію [10].

Духовний потенціал особистості не $\epsilon$ величиною постійною, так як в функціональному вимірі свідомість, самосвідомість і воля особистості знаходяться в постійному розвитку. У змістовному вимірі духовність може змінювати свої ідеали, цінності, смисли, так як наукові відкриття збагачують духовний досвід особистості, сприяють його подальшому розвитку.

Актуалізація духовності є перехід від потенційного, неусвідомленого - до активного, проявленого в особистісних потребах і усвідомленого. Духовні потреби не виникають від народження. 3 віком все більшої активності набувають інтелектуальні процеси - сприйняття, увага, пам'ять, мислення, уявлення. Задоволення базових психологічних потреб тягне за собою виникнення потреб соціальних - в любові, повазі, оцінці, самореалізації. Мислення і емоції відносяться до пошуку нових можливостей саморозкриття і реалізації в соціумі.

Активність інтелектуальних і емоційних процесів особистості становить основу для формування вищих психічних функцій - свідомості, самосвідомості, волі, які є проекцією її духовного «Я».

Під впливом духовної мотивації відбувається актуалізація механізмів розвитку духовного потенціалу особистості через механізми ідентифікації, децентрації, рефлексії, трансценденції, усвідомлення буттєвої єдності. Актуалізація психічних механізмів духовного розвитку призводить до активності вищих функцій особистості, духовного «Я», упорядкування (узгодження ідеалів, смислів, цінностей).

Основні смисли духовного порядку пов'язані з найбільш важливими проблемами людського буття, в тому числі з його призначенням, свободою, відповідальністю, самовдосконаленням і духовною самореалізацією.

Таким чином, духовний розвиток - це процес свідомого самовдосконалення особистості в руслі Краси, Доброти та Істини, гармонізації поведінки і способу життя, збагачення духовних придбань людства результатами власної діяльності.

Духовний потенціал накладає відбиток на всі підструктури особистості, яка потенційно виступає регулятором високодуховної діяльності та поведінки людини.

\section{Література}

1. Баевский Р. М., Иванов Г. Г. Методические рекомендации по анализу вариабельности сердечного ритма при использовании различных кардиологических систем. М., 2001. 53 с.

2. Бойчук Ю. Д., Науменко Н. В. Духовне здоров'я: науковий аналіз поняття // Загальна теорія здоров'я та здоров'язбереження: колективна монографія / за заг. ред. проф. Ю. Д. Бойчука. Харків : Вид. Рожко С. Г., 2017. С. 16-26.

3. Гончаренко М.С. Валеопедагогические основы духовности: учебное пособие. Х. : ХНУ имени В. Н. Каразина, 2007. $400 \mathrm{c}$.

4. Діагностичні підходи до визначення стану духовного і морального здоров'я особистості : навчальний посібник для проведення практичних занять / М. С. Гончаренко, Т. М. Куйдіна, Е. Т. Карачинська, В. Є. Новікова. Х. : ХНУ імені В. Н. Каразіна, 2012. 157 c.

5. Загальна теорія здоров'я та здоров'язбереження: колективна монографія / за заг. ред. проф. Ю. Д. Бойчука. Харків: Вид. Рожко С. Г., 2017. 488 с. 
6. Зязюн I. А. Духовна еліта у суспільстві: інтелігентність і громадянськість // Проблеми та перспективи формування національної гуманітарно-технічної еліти : зб. наук. праць / за ред. Л. Л. Товажиянського, О. Г. Романовського. НТУ «ХПІ». Х., 2003. 4.1 (5). С. 32-42

7. Навчально-виховний комплекс «Потенціал»: здоров’язбереження через партнерство : науково-методичний посібник / упоряд. А. П. Малишевська, С. П. Зубик; за наук. ред. С. В. Кириленко. Київ-Чернівці : Буряк, 2018. 444 с.

8. Некрасова М. А. Стан здоров’я учнів Оболонського району м. Києва у цифрах і фактах. С. 112-118.

9. Помиткін Е. О. Духовний потенціал особистості: психологічна діагностика, актуалізація та розвиток : посібник. Київ: «Внутрішній світ», 2015. 144 с.

10. Помиткін Е. О. Збереження здоров’я та розвиток духовного потенціалу учнівської молоді як змістовні орієнтири освітнього процесу // Валеологія: сучасний стан, напрямки та перспективи розвитку : мат. XV Міжнар. наук.-практ. конференції. Харків, 2017. С. 63-67

11. Сенека Л. Философские трактаты. СПб. : Алетейя, 2001. 399 с.

12. Смирнов К. Ю., Смирнов Ю. А. Разработка и исследование методов математического моделирования и анализа биоэлектрических сигналов. СПб., 2001. 43 с.

13. Уолт Р. Основания духовности. М. : Академический проект; Екатеринбург : Деловая книга, 2000.320 с.

14. Франкл В. Человек в поисках смысла. М. : Прогресс, 1990. 368 с.

15. Ханова Ажа. Феномен благодарности. URL: http://www.cloudwatcher.ru/analvtics/5/view/3Q/. 